\title{
LEARNING STRATEGIES THAT CONTRIBUTE TO ACADEMIC EFFICIENCY IN RELATION TO THE BUSINESS SCHOOL STUDENT'S LEARNING STYLES
}

\author{
María de Jesús Araiza Vázquez¹, Mayra Elizabeth Brosig Rodríguez ${ }^{1}$ \\ and Claudia Ivonne Niño Rodríguez ${ }^{2}$ \\ ${ }^{1} P h D,{ }^{2} M A E$ \\ Universidad Autónoma de Nuevo León \\ Ave. Universidad S/N Cd. Universitaria, San Nicolás de los Garza, N.L., Spain
}

\begin{abstract}
In the XXI century one of the main challenges facing the education system at the superior level, is to promote education through the creation of flexible teaching environments, which allow raising the level of autonomous learning in students, that is why, in this research, the study of learning styles and their correlation with academic performance is proposed, demonstrating that if it is taught based on the strategies of each learning style, the flow in the teaching-learning process channel is accelerated, which will favor the development of skills and abilities that build meaningful knowledge.

The results reveal that among the styles of reflexive, active and pragmatic learning there is a correlation between the variables analyzed, while in the students with emphasis on theoretical styles no significant correlation was found. This information shows the importance of establishing strategies for learning style that contribute to improving academic performance.
\end{abstract}

\section{KEYWORDS}

Learning Styles, Academic Performance, Meaningful Learning

\section{INTRODUCTION}

Education has been one of the main axes, in which the government has paid special attention, in its search to achieve development and economic growth in the country.

Due to the nature of this study we will define learning style as, the diversity of ways in which an individual, reveals their abilities to think, understand, and observe the facts or situations. Given that, under the new educational schemes, where students must develop autonomous learning.

The purpose of this study was to propose strategies related to each learning style for the 2nd year students who were studying the learning unit cost elements in a business school in Northeast Mexico in relation to his academic performance. As a delimitation of this study, academic performance is considered the final note or grade of the course obtained by the student, codified in the results of achievement obtained by the students in the integral system for the administration of educational services.

There are studies that show information about learning styles and learning strategies: (Valencia, 2014; García, Gutiérrez, Jiménez \& Sánchez 2012; Cantú Hinojosa, 2004). These investigations reflect results in which learning styles are associated with variables such as effective learning, perceived effectiveness, academic performance, among other factors that underpin deep or meaningful learning.

\subsection{Justification}

The study presented here is justified in the understanding that educational institutions and their teachers are always looking for improvement in their daily work, the purpose is to find better discrepancies in the teaching-learning process, in order to lead to progress of them looking for the improvement of the system actors. 
From the point of view of the researchers this work, should contribute to the student in discovering the way in which it is feasible to learn, at the same time, it will allow the construction of a significant autonomous knowledge, and developing the capacity to take decisions to the challenges that the society of the knowledge demands..

\subsection{Overall objective}

Propose strategies related to each learning style by the students of 4th semester of a business school in the COURSE cost elements in relation to their academic performance.

\subsection{Hypothesis}

H1 Students who do not apply their learning style properly need learn a strategy to pretend optimal academic performance.

H2. Students who apply their learning styles obtain an optimal academic advantage

\section{THEORETICAL FRAMEWORK}

Throughout this research, it has been proven that among the protagonists of education, -student, teacher and educational institutions- there are different ways of learning, and teaching, however nowadays these are subject to the regulations of the new educational models, which allow us to be at the forefront of technological advances, using tools and strategies in journeys to achieve significant student learning, converting the teacher from an active protagonist to a guide, facilitator and mediator of education, there the importance of identifying and directing the strategies that go according to each learning style and thus achieve effective interaction, directed to the teaching-learning process, which contribute to the construction of autonomous knowledge, directing it in the search of an effective academic performance.

\subsection{Academic Performance}

Based on the above considerations, we could appreciate that there is a diversity of studies related to academic performance, usually focusing on two primary aspects: those measured in the teachers and their work in teaching. For this paper, the work and theoretical support projected by Pizarro (1985) was considered as support, and its consideration of the academic performance as "a measure of the respondent or indicative capacities that it shows, in an estimated way, [what a student] has learned as a consequence of a process of instruction or training ".

\subsection{Learning Strategies}

Strategies are techniques that are used as a means to make the learning process effective; There is a large diversity of authors that conceptualize this term, for example (Nisbet and Shucksmith, 1986) "learning strategies are the integrated sequences of procedures or activities that are chosen with the purpose of facilitating the acquisition, storage and / or use of information or knowledge. " And that according to; (Díaz and Hernández 2010 cited in García, et al., 2012) mention "seven learning strategies widely used in educational psychology and pedagogy, directing them according to their learning style: active, reflective, theoretical, pragmatic.

For Cantú-Hinojosa, (2004) "A learning style implies preferences, tendencies and disposition, as well as behavioral patterns that distinguish a subject from the others in the form that acquires and processes the information" (p.73). In the same sense, are the cognitive, effective and physiological features that serve as relatively stable indicators of how students perceive, interact and respond to their learning environments. (Keefe, 1988; cited by Gallegos \& Martínez, 2003, p.4). It is therefore appropriate to emphasize the various ways in which an individual manifest his thinking abilities in order to understand, discern concepts, observations and facts.

Therefore, it is important that each person identifies their learning style, this being a competence that allows them to interact in their social and professional environment. (Acevedo, 2012). 
For Pizarro (1985); "Academic performance is an indicator of the learning that a student presents in terms of skills and abilities, as a result of the participation of an educational situation." In the field of higher education, this issue has gained strength as an indicator of the quality of institutions. (Isaza 2012).

\section{DESCRIPTION OF THE METHOD}

This research is quantitative descriptive and longitudinal applied to a sample of 103 students currently in the fourth semester of January-June 2018 of public accountant in a business school in Northeast Mexico. The sample consisted of 49 men (48\%) and 54 women $(52 \%)$. The course considered in the study was cost elements, which is taken in the 2 nd year of the degree.

Using as a measuring instrument the Honey-Alonso Learning Styles questionnaire with a reliability of .80 of Cronbach's alpha, consists of 80 short and structured questions in four groups of 20 questions corresponding to the 4 styles of learning. The instrument was piloted to check that the vocabulary was related to the context of Mexican culture.

\section{RESULTS}

This research work was carried out by running the data with correlation analysis, frequency distribution and percentages, as well as measures of central tendency. Table 1 shows that the average achievement of the study population is within the accreditation index which is 70 points; with a standard deviation of 15.12 showing a high variance between results, which is considerable; 25 points being the grade with the highest degree of deficiency, while 100 points reflects a high performance rating.

Table 1. Average of achievement of the 103 students in the course

\begin{tabular}{lllllll}
\hline Variable & $\mathrm{N}$ & Mean & Desv. Standard & Rank & Minimum & Maximum \\
\hline & 103 & 70.9708738 & 15.1211652 & 75 & 25 & 100 \\
\hline
\end{tabular}

Source: Own elaboration with study data.

Table 2 shows that the theoretical style shows a standard deviation of 10.48; which indicates that the students' achievement of this learning style is very attached to academic performance, accepted by the institution under study (according to quality indicators $>85$ ).

The Pragmatic style obtained a standard deviation of 19.98, and the Active reflected a standard deviation with a course of 16.93 , both with similar standard deviation.

In the expected of the rates, the Pragmatic and Active return to similar: Pragmatic with a score average of 67 and the Asset with an average of 65.36.

On the other hand, the reflective learning style shows a mid-range style in measure, with a significant standard deviation between its data with a of 14.75 , being the learning style with the best academic performance with respect to its mean with a value determined of 74.19 points.

Table 2. Average and Standard deviation by style of Learning in course Cost Elements

\begin{tabular}{lll}
\hline \multirow{2}{*}{ Learning styles } & \multicolumn{2}{l}{ Average } \\
& Rates & Desv. Standard \\
\hline Active & 65.36 & 16.93 \\
Reflexive & 74.19 & 14.75 \\
Theoretical & 73.78 & 10.48 \\
Pragmatic & 67.00 & 19.98 \\
\hline Source: Own elaboration with data collected
\end{tabular}


Table 3. Academic performance $<84,>85$ in the course Cost Elements for learning styles

\begin{tabular}{|c|c|c|c|c|}
\hline \multirow[t]{2}{*}{ Learning styles } & \multicolumn{2}{|c|}{$\begin{array}{l}\text { Rates } \\
\text { Percentage }\end{array}$} & \multicolumn{2}{|c|}{$\begin{array}{l}\text { Rates } \\
\text { Subjects }\end{array}$} \\
\hline & $\leq 84$ & $\geq 85$ & $\leq 84$ & $>85$ \\
\hline Active & $91 \%$ & $9 \%$ & twenty & two \\
\hline Reflexive & $67 \%$ & $33 \%$ & 18 & 9 \\
\hline Theoretical & $81 \%$ & $19 \%$ & 30 & 7 \\
\hline Pragmatic & $82 \%$ & $18 \%$ & 14 & 3 \\
\hline
\end{tabular}

Source: Own elaboration based on the data obtained

In Table 3 we can see in the Active style, $91 \%$ of the students who developed this style obtained an average grade of $<84$, thus being the learning style with the largest number of subjects, with a lower academic performance. Only $9 \%$ of the students of this learning style obtained an average grade $>85$.

In the Reflective style, $67 \%$ of the students who developed this style obtained an average of $<84$, while the students who obtained an average $>85$ were $33 \%$. Being the style that shows the highest index of subjects in the variable $>85$.

The Theoretical Style reflects in the variable $<84$ an $81 \%$ leaving $19 \%$ in the variable $>85$; finally, the Pragmatic learning style which obtained $82 \%$ in the variable $<84$ and an 18 in the variable $>85$

In figure. The Reflective style shows a non-significant positive correlation derived from its academic performance demonstrated by its $\mathrm{R}^{2}(0.1112)$ and its ascending slope $(0.0448)$ which indicates that these students with respect to the learning style will obtain a good result in the learning unit Cost Elements.

In Figure 2. The Pragmatic learning style shows a positive relationship (0.2073) however its negative slope $(-0.0267)$ clarifies an offspring due to the few students that show a good academic level.

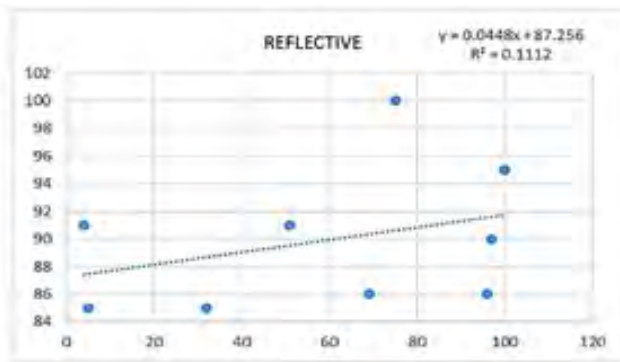

Figure 1. Correlation coefficients and Reflective significance vs. performance academic Source: Elaborated by the authors

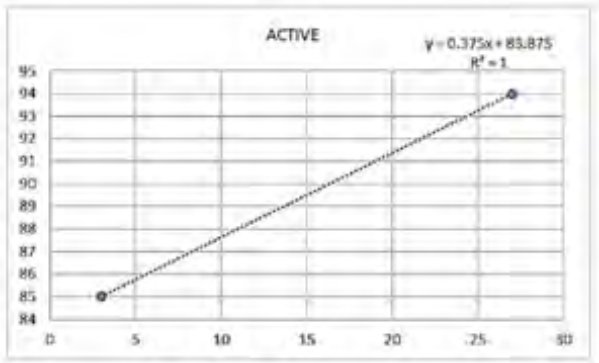

Figure 3. Correlation coefficients and significance of the asset vs. the performance academic Source: Elaborated by the authors

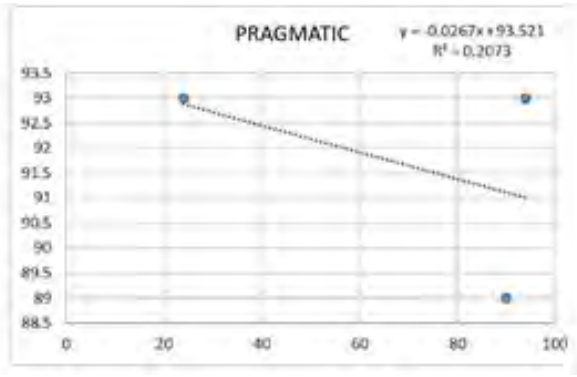

Figure 2. Correlation coefficients and significance of the pragmatics vs. the academic performance Source: Elaborated by the authors

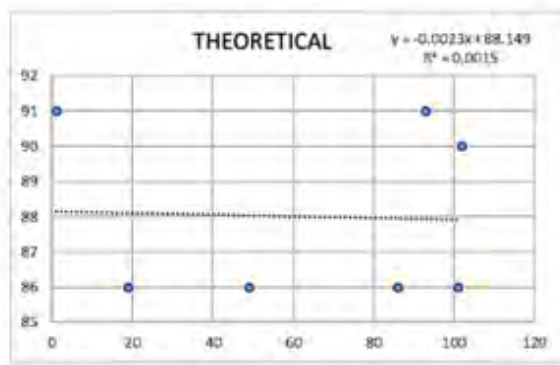

Figure 4. Correlation coefficients and significance of Theoretical vs. academic performance Source: Elaborated by the authors

In Figure 3. The Active learning style shows the highest correlation with the academic level shown by the school (85 points) indicating its $\mathrm{R}^{2}(1)$ and its ascending slope $(0.375)$ which reflects that the academic performance of the students who scored 85 points or above 85 points is acceptable and will look ascending. 
Figure 4 shows the correlation between academic performance and the theoretical learning style, which has a of 0.0015 ; with a slightly downward slope of -0.0023 . These indicate that the students who develop this learning style did not increase their academic performance, but on the contrary, which reduces the use in the course of the cost elements.

\section{CONCLUSION}

This study is of great importance due to the new educational scenarios in the area of quality in Higher Education and changes that bring with it paradigmatic ruptures in the student's teaching-learning process, which hides the search for autonomous learning, hence the importance of the conducive in identifying the strategies directed to each style of learning of the student, this link is directed towards the pretension of an optimal academic performance; That is why the empty contribution that this study throws through the following hypotheses.

This research work aims to identify the learning styles and their correlation with academic performance in course "Cost Elements", in students of the public accountant career of a Business School of the Northeast of Mexico; demonstrated by its slope and $\mathrm{R}^{2}$, by proposing learning strategies; for this purpose, the two alternative hypotheses are approved.

H1: Students who do not apply their learning style well, occupy developing a learning strategy to pretend an optimal academic performance.

Table 3 shows the percentages of students who obtained established scores to measure academic performance, according to the quality standards issued by the institution under study; the learning styles are the following: Active (91\%), Theoretical (81\%) and Pragmatic (82\%) obtained a higher percentage in the average $\leq 84$ of the grade, emphasizing the Active style due to the small number of subjects therefore showing a higher percentage in the variable already mentioned $(<84)$.

In Figure 4, the correlation between academic performance and the "Theoretical" type style is shown, with an $\mathrm{R}^{2}=0.0015$ and its negative descending slope -0.0023 . These indicate that the students who develop this learning style did not increase their academic performance, but on the contrary, that the use of cost elements decreased in the unit of learning. The HI is approved

While Figure 2 indicates that the Pragmatic learning style shows a positive correlation 0.2073; however, its slope is negative -0.0267 because the students in this learning style, require a facilitator to claim optimal academic performance. The $H 1$ is approved

The H2: Students who apply their learning style obtain an optimal academic advantage. This hypothesis is approved with Figure 3, which shows that the "Active" learning style with an $\mathrm{R}^{2}=1$ and its ascending slope is 0.375 , and with Figure 1, where the "Reflective" style is observed with an $\mathrm{R}^{2}=0.1112$ and its ascending slope 0.0448. Both learning styles reflect a significant correlation and an ascending slope, which indicates that students are autonomous in their learning. Table 3 shows $33 \%$ of the students who developed the Reflective learning style, with an average grade $\geq 85$. Because this (Reflective) style has a better academic performance, the approval of this hypothesis is confirmed (H2).

\section{RECOMMENDATIONS}

It is suggested that the teacher at the beginning of each school year apply a questionnaire of Learning Styles to identify and address based on the learning style the teacher; and in this way to link the teaching strategies with the learning styles in communion to the learning unit, being these some of the factors that help the learner in an agile and skillful way to process information that is used in the teaching-learning process by detonating in the development of competences, attitudes and abilities for the construction of an autonomous learning where it probably has repercussions towards the search of an optimal academic performance.

Based on the results obtained from this research and in compliance with the objective, the following learning proposals are presented. With the descriptions that distinguish each learning style, according to the Kolb theory model, we propose the following learning strategies as viable, according to the styles that apply to the students in the LU Cost Elements. a) Analysis and interpretation of real commercial situations, for the 
reasonable determination of the accounting record of a transaction. Which is suggested to the students with Reflective and Theoretical style by facilitating the critical analysis and possessing the ability to carefully observe each of the transactions to make the decision in a well-founded manner, as well as to carry out the process of the information where they use logic by detonating the reasoning in the accounting record of the transactions of an entity. The learner with Active style like the previous ones fits into this same strategy. By developing the ability to solve practical cases based on real situations when considering it as a novel learning experience and attractive in its understanding. The pragmatic style shows an interest in the practical problems of real cases, hence its spontaneous decision-making. b) Solution of online cases (business simulators) to respond to a problem or situation. We recommend for students in the LU Elements of Cost, familiarization with the use of technology and remote applications, which will help them develop and implement other styles, acquiring new skills, attitudes and competencies in the search for problem solving that appear in their environment. c) Determination of flows of information systems based on the application of accounting logic. Consider the theoretical style since it can develop the ability to easily understand the sequence and logic of the processes that are applied in the LU cost elements. On the other hand, Reflective style for its agile ability to observe complex situations and allows them to perform the analysis under a skillful scheme, to establish a detailed conclusion of each situation raised.

\section{REFERENCES}

Acevedo, C, \& Rocha, F. (2011). Estilos de aprendizaje, género y rendimiento académico. Revista Estilos de Aprendizaje, Vol.8, No. 8 octubre; Universidad de Concepción, Concepción, Chile Extraído https://www2.uned.es/revistaestilosdeaprendizaje/numero_8/articulos/1sr_8_articulo_5.pdf

Cantú Hinojosa, I.L. (2004). El Estilo de Aprendizaje y la relación con el desempeño académico de los estudiantes de arquitectura de la UANL.Ciencia UANL. Vol. VII No.1 Enero-Marzo 2004.

Gallego Rodríguez, A., \& Martínez Caro, E. (2003). Estilos de aprendizaje y e-learning. Hacia un mayor rendimiento académico. RED. Revista de Educación a Distancia, (7) p.4.

García, Sánchez, Jiménez y Gutiérrez. (2012). Estilos de Aprendizaje y Estrategias de Aprendizaje: un estudio en discentes de posgrado. Revista de estilos de aprendizaje, Vol.10, No.. 10. Pp.8-9

Isaza Valencia, L. (2014). Estilos de Aprendizaje: una apuesta por el desempeño académico de los estudiantes en la Educación Superior. Revista Encuentros, 12(2), pp.25-34.

Nisbet, J.; Shucksmith, J. (1986). Learning Strategies. Routiedge \& Kegan Paul, Londres. Trad. cast.de Bermejo, A. (1987): Estrategias de aprendizaje. Santillana/Aula XXI, Madrid.

Pizarro, R. (1985). Rasgos y actitudes del profesor efectivo (Tesis de Maestría). Pontificia Universidad Católica de Chile.Mariscal. 